\title{
機動的希ガス分析に向けて: 希ガス元素分析における装置移動の影響評侕の試み
}

\author{
田村 肇 ${ }^{1 a^{*}}$, 熊谷 英憲 ${ }^{1 a}$, 佐藤 佳子 ${ }^{1 a}$, 鈴木 勝彦 ${ }^{1 a}$
}

四重極型質量分析計を装備した超高真空試料真空破砕装置を実験室外に移動して分析を行うことで, 希ガスおよび 共存する炭酸ガス, 水, 窒素のガス分析を機動的に行う可能性を検証した. 移動に際し装置超高真空部の封止に注意 を払うことで, 移動後も実験室内での運用と同程度の $10^{-5} \mathrm{~Pa}$ 台の圧力が維持された. 火山ガスを大量に含む立武岩質 ガラス6K834R4の分析において, ベースラインからの見かけ変動值は最少で, 装置内の分圧として $7 \times 10^{-7} \mathrm{~Pa}$ であた。 今回の結果により, 移送および組み立てにおいて十分な配慮があれば, 所要の電力が供給された観測船や車両において, 流体中の微量ガスのその場分析が可能であるという見通しが得られた.

キーワード：質量分析, 現地機器分析, 希ガス

2009年2月 24 日受領；2009年9月 7 日受理

1 独立行政法人海洋研究開発機構 - 地球内部変動研究センター

現在の所属

$\mathrm{a}$ : 独立行政法人海洋研究開発機構 - 地球内部ダイナミクス領域

代表執筆者：

田村肇

独立行政法人海洋研究開発機構・地球内部ダイナミクス領域

干 237-0061 神奈川県横須賀市夏島町 2-15

046-867-9318

jim-tamura@jamstec.go.jp

著作権: 独立行政法人海洋研究開発機構 


\title{
- Report -
}

\section{Mobile noble gas analysis: A trial of on-site measurement of noble gas elemental abundance}

\author{
Hajimu Tamura $^{1 *}$, Hidenori Kumagai ${ }^{1}$, Keiko Sato $^{1}$, Katsuhiko Suzuki $^{1}$
}

A vacuum sample crushing system equipped with a quadrupole residual gas analyzer was operated out of laboratory and was proved to perform reliable sample analyses of noble gases and coexisting carbon dioxide, water, and nitrogen. Careful sealing at disassembly and assembly maintained the apparatus under ultra high vacuum of $10^{-5} \mathrm{~Pa}$ that is comparable to the pressure in usual operation. The analyses of a gas rich basaltic glass from East Pacific Rise, 6K834R4, represented minimum detection limit down to $7 \times 10^{-7} \mathrm{~Pa}$ as a partial pressure in the instrument; the value was determined as the difference between an apparent value of change from a base line. The result demonstrates the potential of "on-site" gas analyses on fluids on research vessels or vehicles when the sufficient electric power is supplied and the apparatus is treated carefully at transportation and assembly.

Keywords : mass spectrometry, on-sight instrumental analysis, noble gas

Received 24 February 2009 ; Accepted 7 September 2009

1 Institute for Research on Earth Evolution, Japan Agency for Marine-Earth Science and Technology

Corresponding author :

Hajimu Tamura

Institute for Research on Earth Evolution, Japan Agency for Marine-Earth Science and Technology

2-15 Natsushima-cho, Yokosuka 237-0061, Japan

$+81-46-867-9318$

jim-tamura@jamstec.go.jp

Copyright by Japan Agency for Marine-Earth Science and Technology 


\section{1. 序}

地球科学のための希ガス分析においては，可搬測定 に対する需要が広く存在する. 地質活動と関連すると 考えられる噴気や湧水のような湧出現象での希ガス元 素の存在度や同位体比の変動は, 時間的にも空間的に も, ガス供給の契機となる地質活動の変化を示唆する. こうした希ガス組成の変動の検出のために, 現地より 試料を採集し，実験室内で同位体組成等を分析してい る例としては, Sano and Nakajima (2008)など多数の例 がある. ガス試料は, 大気中での採取による混染が避 けられず，保管による試料の劣化が生じやすいという 欠点もある.このため, 対象とする湧出現象の場に分 析装置を携行することは, より新鮮な試料での分析を 可能にするという利点がある．また試料を採集する場 合運搬能力や採集容器の数の制約から単位時間あたり の試料数が制約されてしまう. 現地での分析であれば, 分析に要する時間によって決まる限界まで高密度での 分析が可能である。希ガス同位体分析に用いられる扇 形磁場型質量分析計は, 構造上振動に弱くかつ大型で あるため，簡便に携行が可能な装置とすると分析が元 素組成に限られる。 そのような制約があるとはいえ， 現地分析の利点は大きく, さらに, 現地で得られた情 報にもとづき高価值の試料をその場で選別することで 実験室での試料分析をより絞り込んだ形で行うことも 可能になる。例えばZimmer and Erzinger (1995)ではド イッの大陸地殼掘削プロジェクトであるKTBに扔いて 掘削泥水からガスを採取し, 希ガス元素存在度を含む 微量ガス元素濃度をモニターしている. 海洋研究開発 機構は観測・調查に立脚した海洋地球科学研究を実施 する機関であり，観測・調查の現場における試料情報 の収集手段を充実することは必須であろう、機動的希 ガス分析は噴気や湧水のような湧出を伴う地質活動の 時間的空間的な変動に関わる調查・観測において有用 である.

気体試料中の希ガス元素の分析には，通常質量分析 法を用いる. 質量分析は分子量の違いにもとづいて試 料の組成を分析する手法である. 試料分子はイオン源 でイオン化され, 電場による加速を受けた後, 分析部 で質量数と荷数の比 $(\mathrm{m} / \mathrm{z})$ にもとづいて分離される. 分 離されたイオンは検出部でイオン電流として検出される.

希ガス質量分析においては, 装置内の圧力を $10^{-5} \mathrm{~Pa}$ 以下の超高真空に保つことが必須である. $m / z$ にる イオン飛跡の違いを利用して分析を行うには, イオン が他の分子に衝突することなくイオン源から検出部ま で飛行することが必要である。すなわち装置内に扔け る気体分子の平均自由行程がイオン源から検出部まで
のイオンの飛行距離を上回っている必要があり, こ こから装置内の圧力の上限が定まる (de Hoffmann and Stroobant, 2002). また, 希ガス元素のイオンの $m / z$ は比 較的小さく, 大気中に含まれる希ガス元素や大気に含 まれる希ガス以外の物質のイオンの $m / z$ と重なるため, これらをできる限り取り除くためにも装置内の圧力を 低く保つ必要がある. $10^{-5} \mathrm{~Pa}$ 以下の圧力が求められる のはこのためであるが, 装置を単純に排気するのみで は内面に吸着性の高い物質が残留する。このような物 質が分析の際に再放出されると, その中で希ガス元素 に近い $m / z$ を持つようにイオン化されたものは, 希ガ ス元素のイオンビームと重なって検出され, 分析を妨 害してしまう，真空容器を排気しつつ加熱すること(ベー キングと称する)などにより, 吸着性の高いガス種を含 めて装置内の残留ガスを充分に取り除き, その状態を 保つことが重要である.

機動的希ガス分析においては, 装置の移動の際に装 置の停止㧍よび分解を行うことが考えられる. 車両な どの輸送機材が測定作業が可能な状態の装置を搭載す るだけの空間を持ち, かつ十分な電源を搭載していれば, 装置の移動に伴って装置を停止ないしは分解する必然 性は必ずしもない. しかし分析を実施する地点の道路 事情や輸送に際しての特殊事情から，そのような前提 を満たす大型の機材を用いて輸送できない状況があり うる.

そのような装置の停止扔よび分解に扔いて, 装置内 の圧力が高くなり, あるいはこれも含めて装置内部を 污染する可能性がある. これは, 超高真空を作り出す 真空ポンプとしてターボ分子ポンプを用いるための必 然的リスクである.ターボ分子ポンプは音速付近で回 転する回転翼によって分子の移動方向や運動速度をそ ろえ, 低真空側に向かって分子の流れを作り出して排 気を行うポンプである(堀越, 1994). 気体を装置外に 排出し, 動作中に装置内を污染しない形式の超高真空 ポンプとして唯一の選択肢であるが, 回転翼を安定し て回転させる機構は振動に弱く, 装置を運搬する際に は停止する必要があり, その際に内部には低真空側か ら気体が逆流し, ポンプ内部を污染する。 また, ター ボ分子ポンプは大気圧からの排気能力を持たないため, 始動時の粗引き用, および, 動作中に排気側圧力を下 げる目的で，しばしばオイルロータリーポンプが用い られる.オイルロータリーポンプは, 故障が少なく大 量の気体を排気する能力を持つが, 動作中であっても, 使用している油の蒸気が高真空側に存在する. したがっ て, ターボ分子ポンプを停止すると, 油蒸気が高真空 側へいわば「逆流」するため, 大気以上にポンプ内部 
を污染してしまう。このため，ターボ分子ポンプを組 み込んだ真空装置は，移動の際には一度装置を停止し， オイルロータリーポンプを高真空側容器から切り離す 必要がある。このときにも装置内部が污染されないよ う, バルブの開閉とポンプの停止の順序を適切に処置 し，油蒸気の流入を防ぐことが重要である。これは， 移動中のみならず，移動が完了してポンプを起動した 後も，移動中に発生したポンプの污染が装置の超高真 空部に及ばないようにすることを含む。そのためには， 12 時間程度ポンプを含めて装置全体のベーキングを行 う。しかしながら，加熱用のヒーターが大電力を消費 すること，脱ガスとその後の装置の冷却に一昼夜程度 の時間が必要であること，また質量分析計は一般に加 熱脱ガス後に調整が必要になることから, 機動的希ガ ス分析においては，装置全体の加熱脱ガスを移動後に 行うことは，避けることが望ましい，また，移動に伴 う振動は, ターボ分子ポンプ回転翼の損傷だけでなく, 分析装置や配管の気密を損う可能性がある.

本研究では，将来的な機動観測を念頭に，装置移動 に伴う分析への影響を評価するため，JAMSTEC 横須賀 本部構内で実際に装置を移動し, 移動の前後に試料の 分析を行い, 比較試験を行った。

\section{2. 機材および試料}

今回用いた真空試料破砕装置(Fig. 1)は，横須賀本 部に設置された希ガス質量分析装置 (Sato et al., 2005; Tamura et al., 2005)の一部として，2002年度より必要な 部品の収集を開始し，2003年度に組み立てを行い，運 用を開始したものである。試料破砕管と四重極型質量 分析計 Stanford Research Systems 製 RGA200を含む超高 真空部分(Fig. 1のB〜D)がひとつの架台に載っており, コイル電源およびRGA200の制御部を別途用意すれば 希ガス質量分析装置と切り離しての運用も可能である. 四重極型質量分析計は分析部が固定された電極のみか らなるため振動に強い. 本実験のため, 希ガス質量分 析装置から切り離したうえで，真空破砕装置コイル電 源の制御を Adtek System Science 製AXP-PI02を用いた ものに変更した。 RGA200は Stanford Research Systems 製RGA Software ver. 2.30 を用いて制御し，これを動作 させるためのラップトップ型コンピューターを用意した. 超高真空部分においては, 部品の接続にコンフラット (ConFlat $\left.{ }^{\circledR}\right)$ フランジとして知られるナイフエッジ型メ タルシールフランジ(ISO, 1986; 黒河内ほか, 2007)を用 いている. 使用したガスケットは無酸素銅を打ち抜き 加工したものである。 この形式のフランジはベーキン

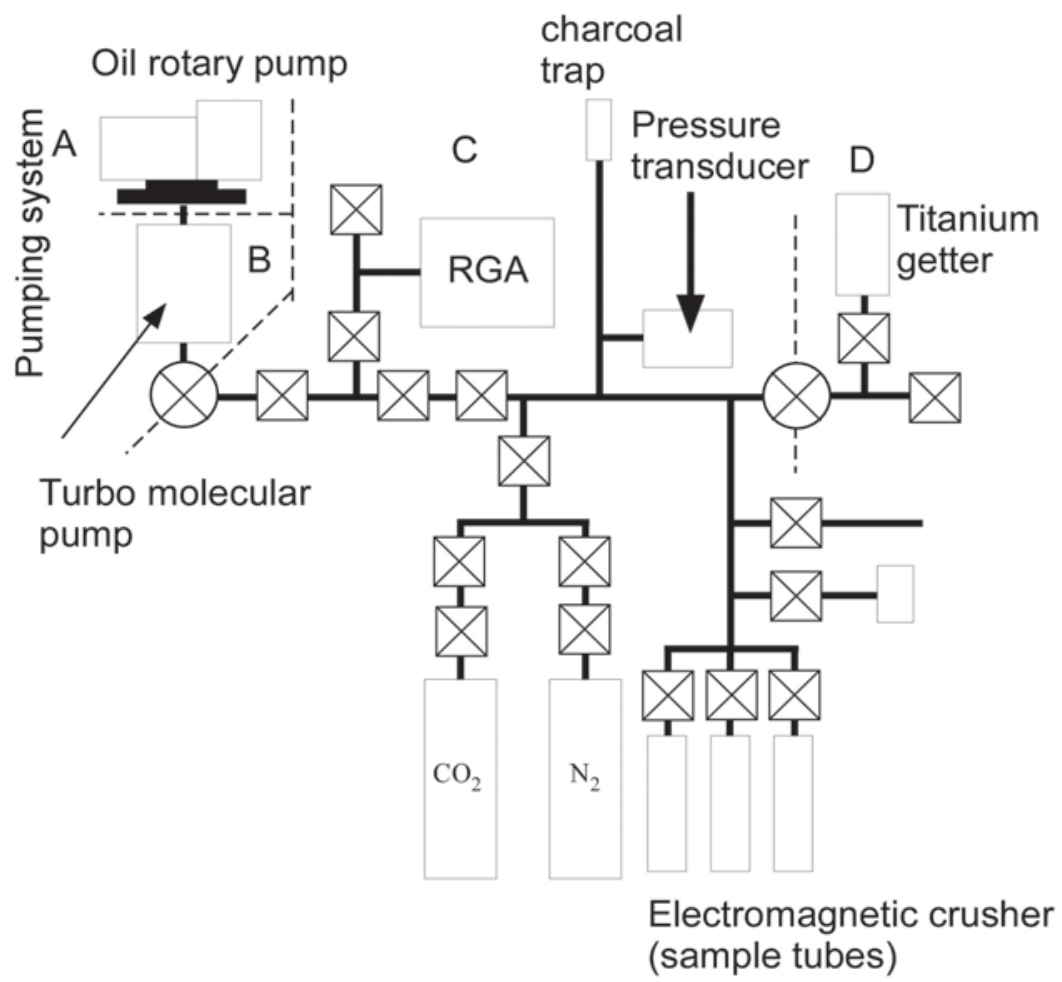

Fig.1. Schematic configuration of the vacuum crushing system modified from Sato et al. (2005). Squares and circles with cross are vacuum valves. Valves marked with circle symbols are operated in the experiment. A - G symbols indicate parts of the instruments which are A; oil rotary pump, B; turbo molecular pump, C; sample preparation and measurement part including the electromagnetic vacuum crusher and RGA200, D; sample purification part, E; electromagnetic coil, F; coil and RGA200 control including PC, G; sample purification apparatus for isotope analysis. 
グ可能な超高真空用フランジとして広く用いられている. オイルロータリーポンプとターボ分子ポンプの接続には, クイックカップリングとして知られる Oリングシール クランプ締めフランジ（日本規格協会, 1988; 黒河内ほ か, 2007）を使用している. この形式のフランジは, ガ

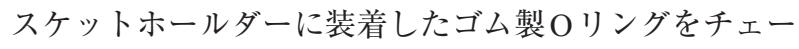
ンクランプで締めつけることで, 容易に着脱でき, か つ高真空を維持するのに十分なシールが得られる（堀越， 1994).

本研究において上記の機材を使用した理由は, そも そもある程度の分解移動を念頭において製作されてい たためである．使用後は確実に原状に復帰することが 必要であるため, 比較のための分析については, 使用 した機材が供えている機能を用いたガラス試料の破砕 分析とした. 本研究は将来実現されるべき分析として 連続ガス分析を想定しているが、これを行うには，ガ スを分析に適した圧力に減圧するためのキャピラリー や流量調節器の追加が必要であり, かつ装置内の污染 やポンプの破損の危険が伴う.

比較のため分析する試料は, 東太平洋海膨での YK04-07航海にて採取された玄武岩質ガラス 6K834R4 であり，多量のガスを含むことが報告されている (Geshi et al., 2007). 本研究では試料由来のガスが容易かつ確 実に検出できることが望ましいため, このような試料 を使用した。

\section{3. 試験手順}

前述の真空試料破砕装置をJAMSTEC 横須賀本部構 内で移動し, 移動の前後で試料のガスを分析することで, 試験を行った，移動に際しては装置を四個の部分に分 解し, 移動後組み立てを行った. 組み立て後は分析の 前に 12 時間排気を行ったが, ベーキングは行わなかっ た。手順の詳細は以下の通りである。装置を Fig. 1のD 部と $\mathrm{G}$ 部の境界で希ガス質量分析装置 $(\mathrm{G}$ 部側 $)$ から切 り離し, 試料を破砕管に封入の上, ターボ分子ポンプ で3 時間排気した。次に $200^{\circ} \mathrm{C}$ で装置全体のベーキン グを 12 時間行い, 室温に冷却してから移動前の分析を 行った. その後, すべてのバルブを閉め, 装置を停止 の上, 超高真空部分 (Fig. 1のB〜D), オイルロータリー ポンプ(Fig. 1のA), コイル (Fig. 1のE), 制御部(Fig. 1 のF)に四分割した. 超高真空部分の移動は, 架台に付 属しているキャスターを用いて, 実験棟 5 階にある実 験室から試験を行う別棟 1 階まで, 通路(アスファルト 敷きの道路を含む) およびエレベーターを経由して手押 しした. それ以外の部分は, 同じ経路で別途移動した。 移動後, 装置の組み立てを行い, オイルロータリーポ
ンプを起動, 30 分後にターボ分子ポンプ(Fig. 1のB)を 起動し，1時間後にすべてのバルブを開放して超高真空 部分の排気を開始した. 12 時間後にバルブV8を閉めて 移動後の分析を行った. 移動後の排気中, ベーキング は一切行わなかった.

分析に際しては, 破砕管から四重極型質量分析計ま でをV1を閉めて静作動状態とし, 測定を行いつつ試 料を破砕することで, 測定值の変動を観察した。分析 時の設定を Table 1 に示す。测定を行う $\mathrm{m} / \mathrm{z}$ は, 試料か ら破砕により放出が期待されるガス種とバックグラウ ンドに由来する可能性があるガスを含むように $m / z$ : 4，14，18，40，44とした. すなわち, 試料から放出 されたガスの指標として希ガス元素のヘリウムとアル ゴンを選び，もっとも強いピークが得られると考えら れる $\mathrm{m} / \mathrm{z}: 4\left({ }^{4} \mathrm{He}^{+}\right)$および, $40\left({ }^{40} \mathrm{Ar}^{+}\right)$を測定することとし た. バックグラウンドに由来しうるガスとしては水, 窒素, 炭酸ガスを選び, それぞれ $m / z: 18\left({ }^{1} \mathrm{H}_{2}{ }^{16} \mathrm{O}^{+}\right), 14$ $\left({ }^{14} \mathrm{~N}^{+}\right.$ないしは $\left.{ }^{14} \mathrm{~N}_{2}{ }^{2+}\right), 44\left({ }^{12} \mathrm{C}^{16} \mathrm{O}^{2+}\right)$ を測定した。 窒素は $m / z: 28\left({ }^{14} \mathrm{~N}_{2}^{+}\right)$がもっとも量が多いと考えられるが, 使 用したRGA200では相当量の一酸化炭素 $\left({ }^{12} \mathrm{C}^{16} \mathrm{O}^{+}\right)$が $\mathrm{m} / \mathrm{z}$ : 28 に見られるため, 干渉の少ないと考えられる $\mathrm{m} / \mathrm{z}$ : 14 を用いた。また窒素に由来する $\mathrm{m} / \mathrm{z}: 14$ のイオンは ${ }^{14} \mathrm{~N}^{+}$ないしは ${ }^{14} \mathrm{~N}_{2}{ }^{2+}$ の二種類があるが, 他の物質で見る 限り使用したRGA200での二価イオン生成率は高くな いため, イオン源で窒素分子が分解されることによる ${ }^{14} \mathrm{~N}^{+}$が主体であると考えられる。分析に用いたRGA200 はファラデー検出器とより高感度のContinuous Dynode Electron Multiplier(CDEM) 検出器の二種類の検出器を備 えているが, 上述のうちもっともガス量が少ないと考 えられるへリウムのみ CDEM検出器を用い, 他はファ ラデー検出器を使用した. CDEM検出器は二次電子増

Table 1 Operating setting of RGA Software in this experiment. Target rows contain target materials and the specific settings for each target material. CDEM and Faraday in the detector column specify the detector type to measure the material. See text for difference in detection mechanism between them. Integration row denotes integration time of a measurement in second, and display style row denotes the mode of measurement and style of partial pressure display.

\begin{tabular}{|l|lrl|}
\hline \multirow{4}{*}{ Target } & Material & $m / z$ & Detector \\
\cline { 2 - 4 } & Helium & 4 & CDEM \\
\cline { 2 - 4 } & Nitrogen & 14 & Faraday \\
\cline { 2 - 4 } & Water & 18 & Faraday \\
\cline { 2 - 4 } & Argon & 40 & Faraday \\
\cline { 2 - 4 } & Carbon dioxide & 44 & Faraday \\
\hline \multirow{2}{*}{ Integration } & \multicolumn{3}{|c}{} \\
\hline Display style & \multicolumn{3}{|c}{ Pressure vs. Time, logarithmic } \\
\hline
\end{tabular}


倍管の一種である(Stanford Research Systems, 1996).二 次電子増倍管による信号増幅は, 増幅率が高く, ファ ラデー検出器の出力を電子回路によって増幅した場合 と比べて暗電流の影響が少ないため, 微小なイオン電 流を検出できる。一方で増幅率がイオンの入射速度に 依存し，長期的に不安定であること，強いイオンビー ムを入射させると劣化することから，高濃度のガスの 検出には向かない(Habfast, 1997).

測定值の読み取りに際しては, 破砕前の測定値と破 碀後の測定值の差を読み取り，この差を放出量と見な した，RGA Software は指定した $m / z$ を順に測定し，時 刻順に出力する動作モードを持っている。この動作モー ドを用いて，測定值を収録し，測定値が急激に増加し た時点を境として，その直前を破砕前のブランク測定 值とし，その後，測定值の変動が見られなくなった部 分を破砕後の試料ガスの測定値として用いた。またガ ス種によっては真空装置内の減衰の傾向が異なるため, 測定值のピークの頂点を破砕後の測定值とした。この 測定值の決定の詳細については後述する.

\section{4. 結果}

試料ガス分析時の RGA200 の出力変動の例を Fig. 2 に 示す．破砕により最大数桁程度出力が立ち上がっている. 出力の代表值の読み取りに際しては, ヘリウムおよび アルゴンについては平坦部の值を用いた，平坦部に先 立つ尖頭部についてはTamura et al. (2006)にてポスター 報告している。窒素と水は徐々に立ち上がり，10分程 度の分析では平坦部もしくは極大值を得られなかった。 このためデータの最高值を代表値としており，過小評 価の可能性もある。炭酸ガスでは立ち上がってピーク を形成した後，減衰を示している。これはガス分子が イオンソースで分解するためと考えられる。このためピー クトップの值を代表値として用いた．窒素と水の挙動

Table 2 Comparison between pre- and post-relocation states of the instrument.

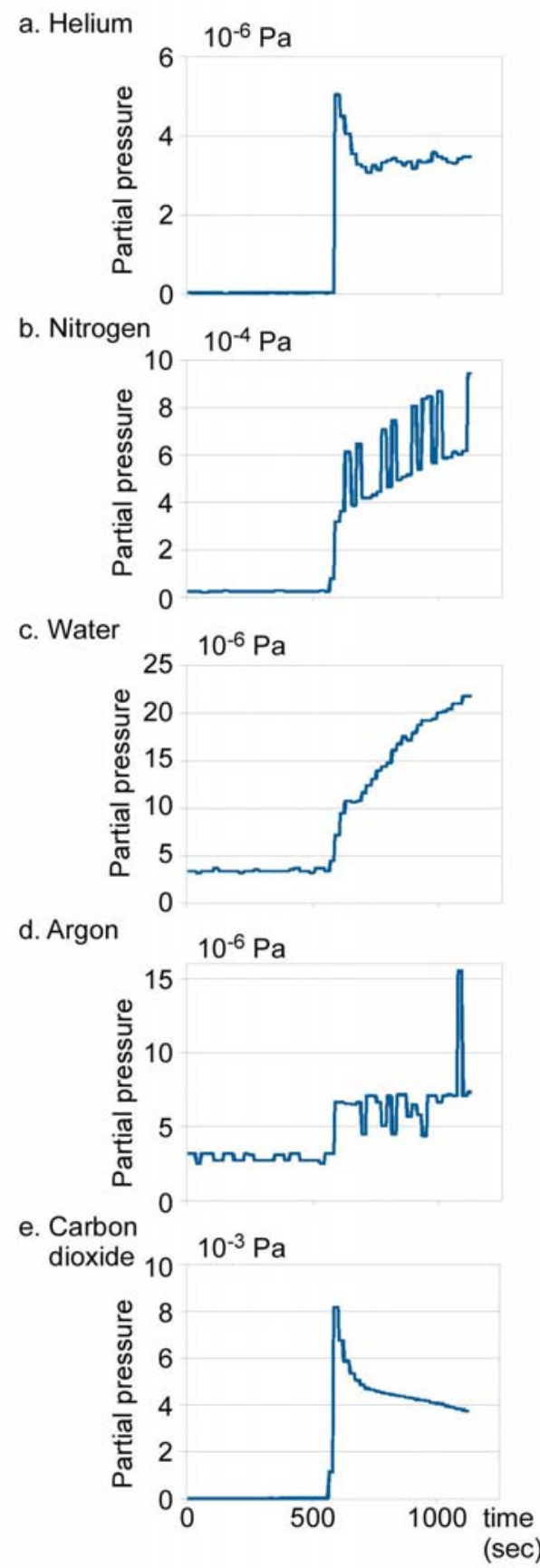

Fig.2. Typical snapshots of gas release. Time scale of each graph is same. a; helium, b; nitrogen, c; water, d; argon, e; carbon dioxide.

\begin{tabular}{|c|c|c|c|c|}
\hline & \multicolumn{2}{|c|}{ Pre-relocation (Pa) } & \multicolumn{2}{|c|}{ Post-relocation (Pa) } \\
\hline \multirow[t]{2}{*}{ Total Pressure (blank) } & \multicolumn{2}{|c|}{$4.5 \times 10^{-5}$} & \multicolumn{2}{|c|}{$3.2 \times 10^{-5}$} \\
\hline & Before crushing $(\mathrm{Pa})$ & Released $(\mathrm{Pa})$ & Before crushing (Pa) & Released (Pa) \\
\hline Helium & $2.0 \times 10^{-8}$ & $1.2 \times 10^{-7}$ & $2.6 \times 10^{-8}$ & $4.2 \times 10^{-7}$ \\
\hline Nitrogen & $4.7 \times 10^{-6}$ & $1.6 \times 10^{-4}$ & $2.5 \times 10^{-6}$ & $3.1 \times 10^{-5}$ \\
\hline Water & $8.4 \times 10^{-6}$ & $5.9 \times 10^{-5}$ & $3.2 \times 10^{-6}$ & $1.1 \times 10^{-5}$ \\
\hline Argon & $2.2 \times 10^{-6}$ & $1.2 \times 10^{-5}$ & $2.7 \times 10^{-6}$ & $4.8 \times 10^{-6}$ \\
\hline Carbon dioxide & $3.0 \times 10^{-5}$ & $8.5 \times 10^{-3}$ & $2.0 \times 10^{-5}$ & $8.3 \times 10^{-3}$ \\
\hline
\end{tabular}


は明らかにヘリウム，アルゴン，二酸化炭素と異なる。 出力の増加が続く期間が長いことから試料からのガス 放出とは考えにくいので，イオン源での炭酸ガスと水 素の反応による一酸化炭素と水の生成を見ている可能 性もある。二酸化炭素の多い条件での分析については, 詳細な検討が必要であろう。また窒素とアルゴンにつ いては，スパイク状のピークが生じている。このスパ イク状ピークは，他の測定ではスパイク状ピークでは なく矩形波状の増減として見えていることもある。ま ずイオン電流值のデジタル化の際の量子化の影響を疑っ たが, より小さな単位で増減を生じている部分がある ので異なる現象と考えられる。スパイク状であるとは いえ10秒程度継続している現象であるため, 電気的な 雑音とも考えにくい. イオン化の不安定であれば，量 としては同程度で, よりイオン化しにくいへリウムに 同様の傾向があってしかるべきと考えられるが，その ような現象は観察されていない. ヘリウムや水で見ら れないことから考えて分圧条件のみで生じるものでは なく，また $m / z: 40$ ないしはこれに近い值を持つイオン で ${ }^{40} \mathrm{Ar}^{+} よ り$ 多量に存在するものは考えにくいので, 質 量分解能が小さいことによる他のイオンビームからの 影響とも思われない。 ここでは, 窒素についてはスパ イク状ピークの最大值を, またアルゴンについては平 坦部の平均值を代表值とした.

移動前および移動後の分析結果を Table 2 に示す．移 動の前後で破砕前の全圧や窒素, 炭酸ガス, 水の測定 值に大きな増加はなく, むしろ全圧や窒素, 水, 二酸 化炭素については減少している。これは移動前の装置 の冷却が十分でなかったことを示唆するが, 一方で移 動や分解による大気の漏れこみはなかったと考えられる。 炭酸ガスの測定值も移動の前後で増加していないので, 装置内はオイルロータリーポンプの油のような有機高 分子によって污染されていないと考えられる．移動前 の超高真空部の圧力は, $4.5 \times 10^{-5} \mathrm{~Pa}$ であった. 封止中 の超高真空部の圧力は, 移動の前後で $10^{-4} \mathrm{~Pa}$ 台に保た れた。 また，バルブV1の開放によって，超高真空部分 の圧力は $10^{-5} \mathrm{~Pa}$ 台に改善した。この圧力は希ガス質量 分析装置から分離する前の超高真空部分の圧力と同等 であり，上述の通り 12 時間の排気によってさらに減少 し， $3.2 \times 10^{-5} \mathrm{~Pa}$ となった。移動の前後における破砕前 の測定值は, ヘリウムとアルゴンはほぼ等しいが, 窒素, 水, 二酸化炭素は半分程度に減少している. 移動に伴っ て装置に漏れが発生したのであればすべてのガスが顕 著に増加するべきであるから，それが見られないとい うことは漏れは発生していなかったと言うことができる. 一方ここで減少しているガスは大気に由来し, 試料や
Table 3 Partial pressures of measured gases in the experiment.

\begin{tabular}{|c|c|c|c|c|c|}
\hline \multirow{2}{*}{$\begin{array}{l}\text { Number of } \\
\text { crushing }\end{array}$} & Helium & Nitrogen & Water & Argon & $\begin{array}{l}\text { Carbon } \\
\text { dioxide }\end{array}$ \\
\hline & $10^{-7} \mathrm{~Pa}$ & $10^{-6} \mathrm{~Pa}$ & $10^{-6} \mathrm{~Pa}$ & $10^{-7} \mathrm{~Pa}$ & $10^{-4} \mathrm{~Pa}$ \\
\hline 1 & 41.9 & 30.6 & 10.6 & 47.9 & 83.4 \\
\hline 2 & 37.0 & 66.3 & 28.3 & 45.4 & 83.9 \\
\hline 3 & 36.8 & 78.0 & 88.7 & 43.8 & 83.9 \\
\hline 4 & 29.7 & 91.9 & 18.5 & 43.8 & 81.6 \\
\hline 5 & 29.7 & 95.0 & 21.9 & 32.6 & 79.4 \\
\hline 6 & 20.9 & 63.8 & 9.8 & 37.4 & 62.1 \\
\hline 7 & 21.3 & 60.6 & 10.1 & 39.8 & 63.1 \\
\hline 8 & 32.9 & 19.8 & 11.3 & 33.0 & 66.6 \\
\hline 9 & 20.3 & 32.6 & 9.0 & 19.6 & 62.8 \\
\hline 10 & 18.3 & 54.9 & 15.8 & 18.6 & 65.0 \\
\hline 11 & 4.0 & 8.9 & 22.3 & 20.1 & 8.2 \\
\hline 12 & 12.7 & 17.4 & 8.8 & 34.6 & 64.3 \\
\hline 13 & 13.8 & 40.5 & 9.4 & 35.8 & 103.5 \\
\hline 14 & 10.7 & 15.3 & 6.4 & 23.0 & 50.0 \\
\hline 15 & 10.1 & 22.2 & 15.4 & 34.6 & 56.4 \\
\hline 16 & 11.5 & 24.1 & 9.7 & 18.6 & 60.3 \\
\hline 17 & 13.7 & 33.7 & 29.9 & 32.6 & 76.4 \\
\hline 18 & 10.3 & 31.1 & 26.5 & 13.7 & 66.4 \\
\hline 19 & 10.4 & 23.9 & 27.5 & 39.4 & 66.4 \\
\hline 20 & 12.2 & 26.5 & 13.4 & 23.4 & 67.3 \\
\hline 21 & 10.4 & 22.0 & 24.5 & 31.0 & 62.0 \\
\hline 22 & 11.2 & 30.6 & 22.7 & 32.6 & 66.7 \\
\hline 23 & 11.0 & 29.4 & 25.9 & 31.0 & 66.2 \\
\hline 24 & 10.1 & 22.9 & 26.3 & 34.2 & 69.8 \\
\hline 25 & 10.1 & 20.8 & 22.2 & 19.3 & 63.5 \\
\hline 26 & 8.8 & 21.1 & 23.0 & 25.8 & 62.0 \\
\hline 27 & 9.2 & 21.5 & 28.0 & 20.0 & 52.5 \\
\hline 28 & 10.6 & 21.1 & 21.4 & 20.0 & 42.8 \\
\hline 29 & 10.7 & 25.0 & 74.4 & 25.0 & 62.5 \\
\hline 30 & 11.0 & 20.0 & 75.9 & 25.0 & 63.5 \\
\hline 31 & 9.8 & 18.4 & 18.5 & 20.9 & 50.4 \\
\hline 32 & 10.4 & 24.1 & 19.6 & 18.5 & 47.3 \\
\hline 33 & 10.9 & 19.4 & 16.4 & 11.2 & 17.6 \\
\hline 34 & 12.2 & 23.1 & 17.2 & 15.0 & 39.4 \\
\hline 35 & 9.3 & 19.3 & 15.6 & 14.4 & 29.0 \\
\hline 36 & 10.9 & 23.0 & 16.3 & 11.2 & 23.4 \\
\hline 37 & 11.5 & 15.3 & 15.6 & 14.4 & 29.1 \\
\hline 38 & 11.3 & 23.7 & 18.8 & 15.0 & 30.1 \\
\hline 39 & 11.8 & 16.4 & 15.4 & 15.0 & 32.3 \\
\hline 40 & 12.3 & 18.7 & 11.0 & 11.8 & 27.1 \\
\hline 41 & 8.7 & 17.7 & 13.9 & 12.6 & 16.8 \\
\hline 42 & 10.8 & 14.4 & 13.5 & 12.6 & 18.3 \\
\hline 43 & 10.0 & 17.1 & 16.9 & 11.8 & 22.5 \\
\hline 44 & 10.6 & 17.1 & 17.7 & 11.8 & 28.5 \\
\hline 45 & 9.9 & 16.3 & 14.0 & 10.2 & 22.2 \\
\hline 46 & 8.9 & 14.0 & 13.9 & 11.2 & 21.0 \\
\hline 47 & 8.3 & 14.4 & 13.6 & 8.0 & 14.3 \\
\hline 48 & 8.7 & 13.8 & 14.1 & 6.4 & 12.6 \\
\hline 49 & 8.2 & 14.7 & 11.9 & 5.6 & 9.0 \\
\hline 50 & 8.3 & 16.8 & 14.4 & 6.4 & 9.0 \\
\hline 51 & 9.5 & 15.1 & 12.9 & 8.0 & 17.0 \\
\hline 52 & 8.3 & 17.0 & 14.4 & 6.4 & 9.0 \\
\hline 53 & 8.2 & 15.1 & 12.9 & 8.0 & 17.0 \\
\hline 54 & 10.8 & 15.6 & 13.7 & 11.2 & 25.6 \\
\hline 55 & 3.3 & 18.5 & 8.0 & 10.5 & 14.0 \\
\hline 56 & 6.8 & 16.2 & 12.6 & 8.0 & 11.5 \\
\hline 57 & 6.9 & 20.5 & 12.6 & 8.0 & 11.5 \\
\hline 58 & 8.6 & 14.1 & 11.8 & 11.2 & 15.4 \\
\hline 59 & 10.4 & 29.4 & 20.3 & 14.4 & 30.6 \\
\hline 60 & 10.4 & 29.4 & 20.3 & 14.4 & 30.6 \\
\hline 61 & 5.1 & 19.5 & 13.5 & 6.4 & 10.1 \\
\hline 62 & 6.7 & 14.2 & 10.4 & 6.4 & 10.8 \\
\hline 63 & 8.3 & 14.6 & 12.8 & 11.2 & 14.9 \\
\hline 64 & 8.1 & 15.8 & 13.4 & 8.0 & 13.4 \\
\hline 65 & 6.5 & 17.8 & 10.3 & 11.2 & 11.9 \\
\hline 66 & 7.0 & 14.5 & 11.4 & 8.0 & 11.9 \\
\hline 67 & 8.0 & 23.9 & 14.0 & 6.4 & 7.9 \\
\hline
\end{tabular}




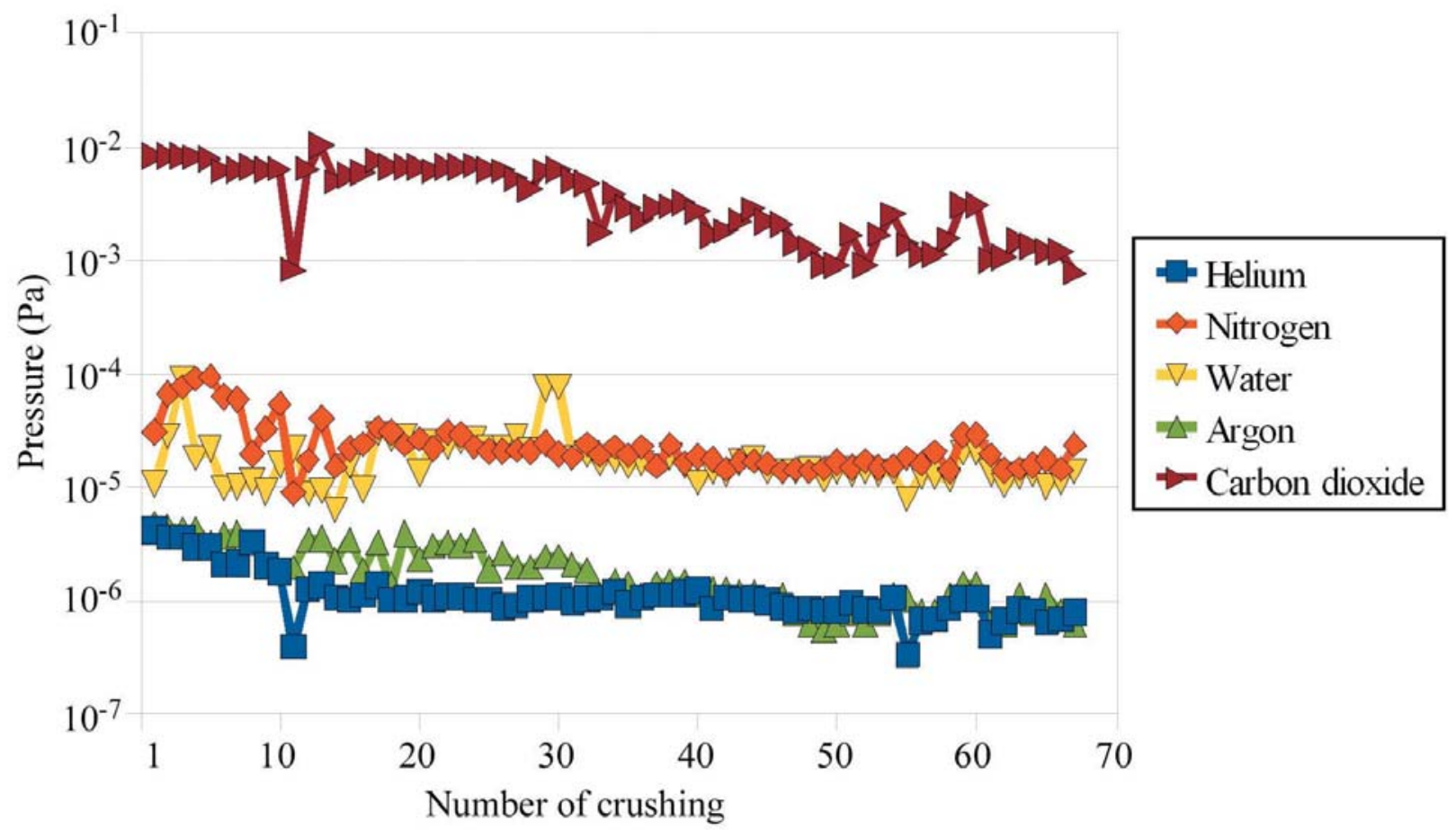

Fig.3. Variation of partial pressures of gases according to number of crushing. Nitrogen and water data are out of order in initial 11 times crushing.

装置内部に吸着していると考えられる物質であり，測 定しているのは物質量ではなく分圧である。したがって, 移動前の分析の時点ではベーキング後の冷却が不十分 であって，見かけ上装置内の圧力が高くなっていた可 能性がある．移動後の測定は移動前の測定の時点から 移動，組み立てと排気をはさんで 14 時間程度経過して から行われており，これにより装置が十分冷却された ことが，移動後にむしろ残留ガス量が減っているよう に見える理由と考えられる.ファラデー検出器でのベー スラインがCDEM検出器に比べて高いのは, 対象とし ているガスの残留量の影響のほか, 先に述べたようにファ ラデー検出器による測定への暗電流の影響という原理 上の限界による。

試料の分析結果は，移動によって装置の分析性能に 支障が生じていないことを示している，移動の前後で ヘリウムが増え, 二酸化炭素が同程度, 他のガスは減っ ている。これは試料のガス放出の傾向による差と思わ れる.この後引き続き 67 回分析を行ったが，最初の数 回では窒素や水は大きな変動を示している (Table 3, Fig. 3). 67 回目での出力はヘリウムが $8.0 \times 10^{-7} \mathrm{~Pa}$, アルゴ ンが $6.4 \times 10^{-7} \mathrm{~Pa}$ であり, 少なくともファラデー検出器, $\mathrm{CDEM}$ 検出器共に $10^{-7} \mathrm{~Pa}$ 程度のガス放出を検出できて いると言うことができる.

\section{5. 結論と展望}

本実験により，四重極質量分析計を計測手段とした 希ガス質量分析装置は，移動および組み立て後の起動 に際して適切な配慮をすれば，搬送しての分析に用い ることができる確証が得られた，移動の際は，ターボ 分子ポンプを主排気用ポンプとしている場合や電源を 確保できない場合は，超高真空部を封止して移送した 上で，封止した状態のまま再起動し，移動の際に大気 にさらされた排気部のみを十分に排気することが必要 になる。ただし，今回対象としたガス種の分析を目的 とするならば，封止移動後に装置全体のベーキングを 行う必要はない。

今後, 水や気体(噴気等)に含まれる希ガスを分析 する場合は試料の導入にあたってもべーキングを必 要としないため, 適切な希釈精製装置を用いること で，装置起動後迅速に分析を始めることが可能である. Erzinger et al. (2006)による現地分析の事例では，四重 極型質量分析計が広い質量範囲を迅速に走査可能であ ることを利用し，連続的に多元素分析を行う形となっ ているが，希ガス組成に着目した場合，試料導入後精 製を行って活性ガスを除去しての高精度分析も有益と 考える．特にネオンをへリウムやアルゴンと比較する ことでガスの起源についての情報が得られるが，ネ才 ンの分析に扔いて, ${ }^{20} \mathrm{Ne}^{+}$と ${ }^{1} \mathrm{H}_{2}{ }^{18} \mathrm{O} /{ }^{2} \mathrm{H}_{2}{ }^{16} \mathrm{O}$ および $\mathrm{Ar}^{2+}$ の 
$m / z$ はほぼ20 と近い值であり, 四重極型質量分析計に よる質量分離は難しい. そのため, 非蒸発性ゲッター などでガスを精製することにより水を除去し, 希ガス のみとした後でさらに低温トラップ分離によりアルゴ ンを除去しなければ分析することができない.ガスの 精製を行うと, 連続的な分析は望めず, 間歇的な分析 の時系列としてデータが得られることになるが, $0.5 〜$ 1 時間につき 1 試料の分析であれば実現可能であると推 定される.

\section{謝辞}

本実験の実施に際し，2005 年横須賀本部一般公開に おける担当者篠塚一典博士を始めとする海洋研究開発 機構地球内部変動センター地球内部試料データ分析解 析研究プログラムの各位, および地球内部変動研究セ ンター研究推進室のご協力をいただいた．また羽生毅 博士には，本装置の機材の使用をご承諾いただいた。 山形大学理学部の齋藤和男教授, 岩田尚能博士および 海洋研究開発機構の木下正高博士には, 査読者として 建設的なご意見をいただいた。本論文の掲載に当たっ ては, JAMSTEC-R編集委員会および事務局のご高配を 賜った．皆様に謝意を表明する。

\section{引用文献}

de Hoffmann, E. and V. Stroobant (2002), Mass Spectrometry: Principles and Applications Second Edition, Wiley, 407 pp.

Erzinger, J., T. Wiersberg, and M. Zimmer (2006), Realtime mud gas logging and sampling during drilling, Geofluids, 6, 225-233.

Geshi, N., S. Umino, H. Kumagai, J. M. Sinton, S. M. White, K. Kushimoto, and T. W. Hilde (2007), Discrete plumbling systems and heterogeneous magma sources of a $24 \mathrm{Km}^{3}$ off-axis lava field on the western flank of East Pacific Rise, $14^{\circ} \mathrm{S}$, Earth. Planet. Sci. Lett., 258, 61-72.

Habfast, K. (1997), Advanst isotope ratio mass spectrometry I: Magnetic isotope ratio mass spectrometers, ed. Platzner, I. T. Modern Isotope Ratio Mass Spectrtometry, Wiley, 11-82.

堀越 源一 (1994), 真空技術 [ 第3 版], 東京大学出版会, $246 \mathrm{pp}$.

ISO (1986), ISO 3669:1986 Vacuum Technology — Bakable flanges - Dimensions, International Standard Organization, $5 \mathrm{pp}$.

黒河内智, 菊地俊雄, 秋道斉, 平田正紘(2007), 真空用 フランジおよび配管継手類に関する国際・国内 規格の概要と相関, J. Vac. Soc. Jpn, 50, 524-526.

日本規格協会 (1988), JIS B8365 真空装置用クランプ形 継手の形状及び寸法, 日本規格協会, 6 pp.

Sano, Y. and J. Nakajima (2008), Geographical distribution of ${ }^{3} \mathrm{He} /{ }^{4} \mathrm{He}$ ratios and seismic tomography in Japan, Geochem. J., 42, 51-60.

Sato, K., H. Tamura, K. Kumagai, and T. Hanyu (2005), Application of K-Ar dating system to be performed by new noble gas mass spectrometry and its calibration from standard air analysis, IFREE REPORT FOR 2003-2004, 2, 1-6.

Stanford Research Systems (1996), Operating manual and programming reference: Models RGA100, RGA200, and RGA300 residual gas analyzer rev.1.6, Stanford Research Systems, 338 pp.

Tamura, H., K. Sato, T. Hanyu, and H. Kumagai (2005), New Noble Gas Isotope Analysis System: Design and Implementation, IFREE REPORT FOR 2003-2004, 2, $1-5$.

Tamura, H., H. Kumagai, and K. Sato (2006), Fine step release of helium, argon, and carbon dioxide from a MORB glass by vacuum crushing and the potential of relocatable noble gas mass spectrometer for preliminary analysis for noble gas research, Geochim. Cosmochim. Acta, 70, A635, doi:10.1016/ j.gca.2006.06.1181.

Zimmer, M. and J. Erzinger (1995), On the geochemistry of gases in formation and drilling fluids - results from KTB, Scientific Drilling, 5, 101-110. 